\title{
EVALUATION OF PEFLOXACIN FOR TREATMENT PEKIN DUCKLINGLING SALMENLLOSIS AT SHARKIA GOVERNORATE WITH SPECIAL REFFERENCE TO ITS RESIDUCE IN TISSUES
}

\author{
Emam, E. E.; El-Nabarawy, E. A.*and Hassan Mohy. E. G.* \\ (Biochemistry and Food Hygiene* Departments) \\ Animal Health Research Institute (Zagazig, Sharkia,Egypt)
}

\begin{abstract}
A total of 120 apparently healthy, one day old Pekin duckling were used to investigate the effect of pefloxacin on Salmonella enteritidis infection. Effect of Salmonella enteritidis and pefloxacin on body weight gain and hemato-biochemical changeswas recorded as well as the residue of pefloxacin in muscles, skin and some organs were determined. Duckling were divided into four equal groups 30 for each). The $1^{\text {st }}$ group apparently healthy duckling (control group), $2^{\text {nd }}$ group was apparently healthy duckling and treated with pefloxacin (5mg / $\mathrm{kgm}$ b.wt.) in drinking water for 5days, while the duckling in $3^{\text {rd }} \& 4^{\text {th }}$ groups were infected with Salmonella enteritidis at the $10^{\text {th }}$ day of age. The $3^{\text {rd }}$ group was kept as infected non treated duckling; Meanwhile the $4^{\text {th }}$ group (infected duckling) was treated with pefloxacin (5mg $\mathrm{kgm} \mathrm{b.wt.)} \mathrm{in} \mathrm{drinking}$ water for 5 day. Five duckling from each group were weighed individually for calculation weight gain for calculation of feed conversion rate at $1^{\text {st }}$ and $21^{\text {th }}$ day post treatment.At $7^{\text {th }}$ and $14^{\text {th }}$ day post treatment 5 duckling from each group were sacrificed for collection of 2 blood samples. The $1^{\text {st }}$ sample was collected for estimation of erythrogram and the $2^{\text {nd }}$ sample was collected to obtain clear serum for estimation some biochemical parameters. Another 5 duckling from each group were sacrificed samples from thigh muscle, liver, kidneys, gizzard and skin were collected at $1^{\text {st }}, 3^{\text {th }}, 7^{\text {th }}$ and 10 thday post treatment for determination drug residuce

Salmonella enteritidis induced $40 \%$ mortality in infected non treated pekin duckling. and $6.67 \%$ in infected group treated with pefloxacin.Healthy ducklings treated with pefloxacin revealed significant increase in the body gain, AST, ALT, alkaline phosphatase, uric acid, creatinine and significant decrease in feed conversion rate,erythrocytic count, hemoglobin content,packed cell volume, total protein and albumin.

Infected ducklings with Salmonella enteritidis and non treated evoked a reduction in body weight gain, albumin and a significant increase in feed conversion rate, AST, ALT, alkaline phosphatase, uric acid, creatinin and globulin. These parameters were improved towards the normal levels when treated infected duckling with pefloxacin.

Pefloxacin residue in the examined samples of liver, kidney, muscles, gizzard,skin
\end{abstract}


and fat were very high at $1^{\text {st }}$ day post treatment then become very low at $5^{\text {th }}$ day,Moreover the pefloxacin completely disappeared from all the examined samples after 7 thdays post treatment days The highest levels of pefloxacin residues were recorded in the liver followed by skin and fat then gizzard and muscles but the lowest levels was observed in the kidneys samples.

From this study we concluded that, pefloxacin has some reversible hepatotoxicity and nephrotoxicity in healthy duckling. Salmonella enteritidis in duckling resulted in adverse effect in both erythrogram and biochemical parameters.

\section{INTRODUCTION}

Duck are a source of protein to human beings. Duck industry in Egypt has been well established; therefore any problems may be common, bacterial diseases are one of the most important problems facing duck industry (Moustafa, et al. 2008). Salmonellosis is one of the most important serious problems threatening poultry industry, where it causes serious economic losses due to high mortality (Seo, et al. 2000). Virulence factors of Salmonella include three general toxins which play role in their pathogenicity, endotoxins associated with cell wall lipopolysaccharides when liberated to circulation during bacte-rial deaths produce fever, liver and spleen lesions (Turnbull and Snoeyenbos, 1974).

Antimicrobial is an important tool in reducing the losses in poultry industry. Among these antimicrobials are fluoroquinolones, which widely used in clinical practice because of their excellent antibacterial effect (Avril, et al. 1995), they act by inhibiting the activity of bacterial DNA-gyrase which responsible for supercoiling of bacterial DNA (Sun, et al. 2001). Pefloxacin is one of a $3^{\text {rd }}$ generation of fluoroquinolones with broad spectrum activity against G+ve, G-ve bacteria and Mycoplasma (García, et al. 1999). Pefloxacin active against all of the Salmonella strains (Wille et al. 1988).

Antibiotic residues in meat derived from treated animals and chickens could pose health threats to consumers, while the constant exposure of some microorganisms to these drugs may manifest itself in development of antibiotic resistant bacteria, allergic reactions in sensitized persons and possible direct toxic effects of minute amounts over long periods of time (Corry et al., 1983).

This work was designed to evaluate the activity of pefloxacin against salmonella enteritidis infection in pekin duckling. Furthermore, effects of pefloxacin and salmonella enteritidis on some hemato-biochemical,parameter as well as drug residuce determination

\section{MATERIAL AND METHODS}

\section{Drug :}

Pefloxacin (Peflodad 10\%) ${ }^{\circledR}$ solution was obtained from Dar Al Dawa Veterinary and Agricultural Industrial Co. Itd. Jordan. Each $\mathrm{ml}$ contains $100 \mathrm{mg}$ of pefloxacin base.

\section{Experimental duckling:}

A total of 120 apparently healthy one day old white pekin ducklings were obtained from 
local commercial hatchery. Duckling were floor reared under complete hygienic condition and fed on a balanced ration free from any medications and given water ad-libitum.

\section{Experimental Design:}

Duckling were divided into 4 equal groups (each of 30 ducklings), $1^{\text {st }}$ group (apparently healthy duckling) was kept as control group while the $2^{\text {nd }}$ group was treated with pefloxacin (5mg / kgm b.wt.) in drinking water for 5 days, $3^{\text {rd }}$ and $4^{\text {th }}$ group were infected with Salmonella enteritidis by $\mathrm{I} / \mathrm{M}$ inoculation at the $10^{\text {th }}$ day of age with a dose of $0.25 \mathrm{ml}$ of 103.3 CFU I/M in thigh muscle (Badr, 2003). $3^{\text {rd }}$ group was kept as infected non treated whereas $4^{\text {th }}$ group infected duckling was treated with pefloxacin (5 $\mathrm{mg} / \mathrm{kgm} \mathrm{b.wt}$.) in drinking water for 5 successive days (Reynolds, 1995). Treatment started $48 \mathrm{~h}$. post infection.

\section{Blood sample}

Five birds from each group were slaughtered at $7^{\text {th }}$ and $14^{\text {th }}$ day post treatment for collection of 2 blood samples. The $1^{\text {st }}$ blood sample was taken for estimation of erythrogram Jain (1986), while the $2^{\text {nd }}$ sample was taken to obtain clear serum for estimation of AST and ALT (Reitman and Frankel, 1957) alkaline phosphatase (John, 1982), uric acid (Trinder, 1969) creatinine (Bartels, 1971). total proteins (Doumas, et al. 1981) and serum albumin (Doumas, 1971) While globulin was calculated as difference between total proteins and albumin,

\section{Body weight}

The live weight was recorded at the beginning of the experiment and at the $1^{\text {st }}$ and $21^{\text {th }}$ post treatment where the weight gain was calculated. The amount of feed used was calculated for determination of feed converation rate.

\section{Drug residue :}

At $1^{\text {st }}, 3^{\text {th }}, 7^{\text {th }}$ and 10thday post treatment a 5 duckling were slaughtered and samples from thigh muscles, liver, kidneys, gizzard and skin were tacken for determination of peflox-acin residues according to Dvorak, et al. (1987) and Roudaut and Moretain (1990).

\section{Statistical analysis :}

The obtained data were tabulated and statistically analysed according to Petrie and Watson (1999).

\section{RESULT AND DISCUSSION}

Our results revealed that most common clinical symptoms in the experimentally Salmon- ella enteritidis infected duckling were loss of appetite, depression and diarrhea. Mortality rate in the infected non-treated duckling was $40 \%$. These results were similar to those rep- orted by Abd Elhamid, et al. (2006) who found that Salmenlosis in chickens induce clinical sign as dropped wings, ruffled feather. Moreover, Greenfield, et al. (1972) ment-ioned that mortality rate ranged between $10-50 \%$ within first week post infection with Salmonella spp. The results evoked that pefloxacin induced reduction in the mentioned clinical symptoms and mortality rate\%. Similar results were reported by Wille, et al (1988) .

Results of this study revealed that pefloxacin induced a significant increase in body weight gain of healthy duckling. These results 
may be due to antimicrobial effect of the drug which consequently improves metabolic activity of the birds. This result was suppor- ted by Bryan, et al. (1998). They postulated that the stimulating growth effect of antimicro-bials resulted from their suppression to the microorganisms that invade the host and retard its metabolic activty. Salmonella enteritidis decreased body weight gain, feed consumption and increase in feed conversion rate in infected duckling. This may be due to deleterious effect of the microorganism which invaded the host and retarded its metabolic activity and decreased absorption of nutrients from the inflamed alimentary tract and diarrhea (Abdallah, Amany 1993). Our results was confirmed with that previously reported by Omyma, et al. (1997) who stated that infected chicks with Salmonella showed decrease in average body weight. Improvment in body weight gain and feed conversion rate were observed post treatment with pefloxacin in infected duckling. The improvement of body gain in infected and treated chicks due to bactericidial effect of the drug (Alexander, 1985).

Our erythrogram data for healthy duckling treated with pefloxacin and infected duckling with Salmonella enteritidis revealed significant decrease in total erythrocytic count haemoglobin content, packed cell volume.Our result coincides with Eslam (2000) who reported that Salmonellosis in chickens induced a significant decrease in erythrocytic count hemoglobin content, packed cell volume \%. Whereas, treatment of infected duckling with pefloxacin induced elevation in these parameters reverting them to nearly their normal values Needless to say, our data clearly reinforced by those obtained previously by Niyogi and Bhowmi. (2003) who found that administration of pefloxacin to birds induced anemia and it possibly resulted from toxic depression of bone marrow or suppression of hematopoietic tissue. These result agreed with the results mentioned by Adel (2004) who found that pefloxacin treatment caused macrocytic hypochromic anemia.Pefloxacin treatment caused elevation in total leukocytic (Kletter, et al., 1992) mentioned that the fluoroquinolone enhances total leukocytic count in the peripheral blood.

In the present study, total proteins, albumin and globulin significantly decreased in healthy duckling treated with pefloxacin and infected non treated duckling. These results are clearly reinforced by Avril, et al. (1995) who suggested that the decrease in protein profile in healthy duckling and treated with pefloxacin due to its immune suppressing effects of this drug. This result agreed with Eslam, (2000) who reported that ciprofloxacin induce significant decrease in total protein due to degeneration or necrosis in liver that reduces protein synthesis. The obtained result were similar to those recorded by Abu Zaid, Omima (1987) who found that Salmonellosis in chicken induced significant decrease in serum total protein,albumin and globulin. Decreased albumin in duckling infected with salmonella enteritidis may be referred to the fact that the liver is the sole of albumin synthesis and hypoalbuminaemina is an important feature of liver diseases (Kaneko, 1989). Duckling infected with salmonella enteritidis and treated with pefloxacin showed improvment in protein profile and returned to nearly normal level at the end of 
experimental period. This indicated that effectiveness of pefloxacin in controling hepatic damage induced by Salmonella enteritidis toxin. This result agreed with (El-Sayed, Nagah, et al. (2004). in laying hens infected with Salmonellosis.

Our findings revealed that, significant elevation in serum AST, ALT and alkaline phosphate in healthy duckling treated with pefloxacin and infected duckling non treated. These findings might be attributed to alteration of membrane permeability or damage of the hepatic cells by direct effect of the drug resulting in escape of these enzymes to the plasma (Coles, 1986) These rresults were supported by Roshdy, (2007) who noted that pefloxacin resulted in elevated liver enzymes in chicken. These changes seem probably to be due to liver damage by the effect of the infectious agent toxins which lead to the escape of these enzymes into serum in abnormal high levels

(Ross, et al. 1976). The increase in serum AST and ALT activity after infection suggest a hepatocellular damage (Doxey, 1971). The present findings are supported by the results recorded by Eslam, (2000) who found that liver ezymes increased in broiler chicks infected with salmonella enteritidis

Results of this study demonstrated that uric acid and creatinine significantly increased in healthy duckling treated with pefloxacin and infected duckling with Salmonella enteritidis. Elevation of uric acid and creatinine levels in healthy duckling and treated with pefloxacin indicating mild damage effect of pefloxacin on the liver and kid- neys Roshdy (2007). These results were supported by Kobayashi (1985) who stated that ciprofloxacin evoked elevat- ion in serum creatinine and uric acid due to its cytotoxic effect. Harrison and Harrison (1986) recorded increase in creatinine levels in case of renal disease and nephrotoxic drugs. On the other hand Dawaud (1992) found that chickens infected with Salmonellosis displaye significant increase in uric acid and creatinine.

Regarding to pefloxacin residues in the chicken liver, muscle, kidney, skin and fat were very high during at $1^{\text {st }}$ day of clearance period and disappeared from all examined organ at 7 thday post treatment expect skin and fat the drug residue disappeared at 15 day post treatment. The highest levels of pefloxacin residues were recorded in the liver followed by skin and fat then gizzard and muscles but the lowest levels was observed in the kidneys samples. The obtained results nearly similar with those reported by Pant, et al. (2005) who mentioned that the concentrations of pefloxacin $(\mu \mathrm{g} / \mathrm{g}) 24 \mathrm{~h}$ after the last administration of the drug declined in the following order: liver $(3 \cdot 20)$, muscle $(1 \cdot 42)$, kidney (0.69), skin and fat (0.06). No drug was detectable in tissues except skin and fat 5 day after the last administration. The concentrations of pefloxacin in skin and fat 10 day after the last dose of pefloxacin were 0.04 and $0.03 \mu \mathrm{g} / \mathrm{g}$.

From this study we concluded that, pefloxacin and Salmonella enteritidis in duckling has some reversible hepatotoxicity, nephrotoxicity and in erythrogram. 
Emam, E. E.; et al...

Table (1) : Effect of pefloxacin and salmonella enteritidis on mortality rate in pekin duckling.

\begin{tabular}{|c|c|c|c|}
\hline \multirow{2}{*}{ Group } & \multirow{2}{*}{ Total No. of duckling } & No. & $\%$ \\
\cline { 3 - 4 } & & - & - \\
\hline G1 & 30 & - & - \\
\hline G2 & 30 & 12 & 40 \\
\hline G3 & 30 & 2 & 6.67 \\
\hline G4 & 30 & & Mortality rate \\
\hline
\end{tabular}

Table (2) : Effect of pefloxacin and salmonella enteritidis on body weight feed consumption and feed consumption rate in pekin duckling $(\mathrm{n}=5)$.

\begin{tabular}{|c|c|c|c|c|c|c|c|c|c||}
\hline \multirow{2}{*}{ Parameters } & \multirow{2}{*}{$\begin{array}{c}\text { Body } \\
\text { weight }\end{array}$} & \multicolumn{9}{|c|}{1 days } & \multicolumn{5}{|c|}{21 days } \\
\cline { 3 - 11 } Groups & 10days & $\begin{array}{c}\text { B.W. } \\
\text { gm/ duck }\end{array}$ & $\begin{array}{c}\text { B.W.G. } \\
\text { gm/ duck }\end{array}$ & $\begin{array}{c}\text { F.C. } \\
\text { gm/duck }\end{array}$ & $\begin{array}{c}\text { F.C. } \\
\text { R }\end{array}$ & $\begin{array}{c}\text { B.W. } \\
\text { gm/duck }\end{array}$ & $\begin{array}{c}\text { B.W.G. } \\
\text { gm/duck }\end{array}$ & $\begin{array}{c}\text { F.C. } \\
\text { gm/duck }\end{array}$ & $\begin{array}{c}\text { F.C. } \\
\text { R }\end{array}$ \\
\hline G1 & $290.71 \pm$ & $430.03 \pm$ & $139.32 \pm$ & 290.36 & 2.08 & $718.37 \pm$ & $288.34 \pm$ \\
1.69 & 1.02 & & & 1.49 & 1.24 & & 4.33 \\
& 1.74 & 1.69 & & & & 124.83 & 4.15 \\
\hline G2 & $294.42 \pm$ & $438.18 \pm$ & $143.76 \pm$ & 296.48 & 2.06 & $742.28 \pm$ & $304.10 \pm$ & 1263.03 & 4.15 \\
& 1.97 & 1.09 & 1.17 & & & 1.31 & 1.37 & & \\
\hline G3 & $295.38 \pm$ & $393.27 \pm$ & $98.34 \pm$ & 250.26 & 2.54 & $568.94 \pm$ & $175.70 \pm$ & 1104.37 & 6.29 \\
& 1.92 & 1.73 & 1.18 & & & 1.92 & 1.21 & & \\
\hline G4 & $298.25 \pm$ & $414.02 \pm$ & $115.77 \pm$ & 274.13 & 2.37 & $697.27 \pm$ & $283.25 \pm$ & 1240.38 & 4.38 \\
& 1.58 & 1.68 & 1.29 & & & 1.28 & 1.59 & & \\
\hline
\end{tabular}

$* \mathrm{P}<0.05$

$* * \mathrm{P}<0.01$

Table (3) : Effect of pefloxacin and salmonella enteritidis on erythrogram in pekin duckling $(\mathrm{n}=5)$.

\begin{tabular}{|c|c|c|c|c|c|c||}
\hline \multirow{2}{*}{ Group } & \multicolumn{3}{|c|}{7 day post treatment } & \multicolumn{3}{c||}{14 day post treatment } \\
\cline { 2 - 8 } & RBCs10 $/ \mathrm{UL}$ & H.b. gm/dl & PCV gm/dl & RBCs10 $/ \mathrm{UL}$ & H.b. gm/dl & PCV gm/dl \\
\hline G1 & $3.42 \pm 0.20$ & $15.59 \pm 0.51$ & $39.83 \pm 1.17$ & $3.12 \pm 0.28$ & $15.38 \pm 0.26$ & $39.36 \pm 1.14$ \\
\hline G2 & $2.06 \pm 0.25^{*}$ & $12.28 \pm 0.33^{*}$ & $36.90 \pm 1.41^{*}$ & $2.91 \pm 0.14$ & $15.12 \pm 0.31$ & $38.17 \pm 1.37$ \\
\hline G3 & $1.94 \pm 0.16^{* *}$ & $11.48 \pm 0.45^{* *}$ & $34.08 \pm 1.67^{* *}$ & $2.07 \pm 0.21^{* *}$ & $12.06 \pm 0.18^{* *}$ & $35.21 \pm 1.06^{* *}$ \\
\hline G4 & $3.31 \pm 0.17$ & $14.08 \pm 0.71$ & $38.33 \pm 1.49$ & $3.07 \pm 0.15$ & $14.21 \pm 0.34$ & $39.08 \pm 1.09$ \\
\hline
\end{tabular}

$* \mathrm{P}<0.05$

$* * \mathrm{P}<0.01$

Mansoura, Vet. Med. J.

Vol. XI, No. 2, 2009 
Table (4) : Effect of pefloxacin and salmonella enteritidis on protein profile in pekin duckling $(n=5)$.

\begin{tabular}{|c|c|c|c|c|c|c|}
\hline \multirow{2}{*}{ ڤ్ } & \multicolumn{3}{|c|}{7 day post treatment } & \multicolumn{3}{|c|}{14 day post treatment } \\
\hline & $\begin{array}{l}\text { T.protein } \\
\text { (gm/dl) }\end{array}$ & $\begin{array}{l}\text { Albumin } \\
(\mathrm{gm} / \mathrm{dl})\end{array}$ & $\begin{array}{l}\text { Globulin } \\
\text { (gm/dl) }\end{array}$ & $\begin{array}{l}\text { T.protein } \\
\text { (gm/dl) }\end{array}$ & $\begin{array}{l}\text { Albumin } \\
(\mathrm{gm} / \mathrm{dl})\end{array}$ & $\begin{array}{l}\text { Globulin } \\
\text { (gm/dl) }\end{array}$ \\
\hline G1 & $4.03 \pm 0.12$ & $2.12 \pm 0.13$ & $1.91 \pm 0.10$ & $4.12 \pm 0.16$ & $2.17 \pm 0.15$ & $1.95 \pm 0.18$ \\
\hline $\mathrm{G} 2$ & $3.02 \pm 0.05^{*}$ & $1.86 \pm 0.03 *$ & $1.16 \pm 0.04 *$ & $3.98 \pm 0.14$ & $2.06 \pm 0.12$ & $1.92 \pm 0.16$ \\
\hline G3 & $2.32 \pm 0.04 * *$ & $1.28 \pm 0.05^{* *}$ & $1.04 \pm 0.05^{* *}$ & $2.30 \pm 0.06^{* *}$ & $1.25 \pm 0.03 * *$ & $1.05 \pm 0.06 * *$ \\
\hline G4 & $3.84 \pm 0.08$ & $2.04 \pm 0.09$ & $1.80 \pm 0.18$ & $3.91 \pm 0.19$ & $2.13 \pm 0.15$ & $1.60 \pm 0.19$ \\
\hline
\end{tabular}

$* \mathrm{P}<0.05$

$* * \mathrm{P}<0.01$

Table (5) : Effect of pefloxacin and salmonella enteritidis on liver enzyemes in pekin $\operatorname{duckling}(\mathrm{n}=5)$.

\begin{tabular}{|c|c|c|c|c|c|c|}
\hline \multirow{2}{*}{ Group } & \multicolumn{3}{|c|}{7 day post treatment } & \multicolumn{3}{c|}{14 day post treatment } \\
\cline { 2 - 7 } & AST(U/L) & ALT(U/L) & Alk.ph. (U/L) & (AST(U/L) & ALT(U/L) & Alk.ph.(U/L) \\
\hline G1 & $39.93 \pm 2.96$ & $20.85 \pm 0.94$ & $14.31 \pm 1.06$ & $39.65 \pm 2.62$ & $20.91 \pm 1.03$ & $14.61 \pm 1.13$ \\
\hline G2 & $44.32 \pm 2.14 *$ & $24.35 \pm 1.12^{*}$ & $21.01 \pm 1.14 *$ & $43.06 \pm 1.89$ & $22.94 \pm 1.57$ & $17.14 \pm 1.51$ \\
\hline G3 & $45.16 \pm 2.16 * *$ & $26.48 \pm 1.31 * *$ & $22.25 \pm 1.17 * *$ & $44.95 \pm 2.03 * *$ & $26.32 \pm 1.23 * *$ & $22.16 \pm 1.21 * *$ \\
\hline G4 & $41.09 \pm 2.05$ & $22.59 \pm 1.72$ & $16.08 \pm 1.25$ & $40.95 \pm 2.17$ & $22.14 \pm 1.46$ & $15.38 \pm 1.37$ \\
\hline
\end{tabular}

$* \mathrm{P}<0.05$

$* * \mathrm{P}<0.01$ 
Emam, E. E.; et al...

Table (6) : Effect of pefloxacin and salmonella enteritidis on kidney function in pekin $\operatorname{duckling}(\mathrm{n}=5)$

\begin{tabular}{|c|c|c|c|c||}
\hline \multirow{2}{*}{ Group } & \multicolumn{2}{|c|}{7 day post treatment } & \multicolumn{2}{c|}{14 day post treatment } \\
\cline { 2 - 5 } & Uric acid & creatinine & Uric acid & creatinine \\
\hline G1 & $3.69 \pm 0.32$ & $0.94 \pm 0.17$ & $3.73 \pm 0.27$ & $0.98 \pm 0.09$ \\
\hline G2 & $5.82 \pm 0.19^{*}$ & $1.92 \pm 0.19^{*}$ & $5.10 \pm 0.14^{*}$ & $1.02 \pm 0.16$ \\
\hline G3 & $5.68 \pm 0.25^{* *}$ & $2.04 \pm 0.21^{* *}$ & $5.05 \pm 0.19^{* *}$ & $2.21 \pm 0.17 * *$ \\
\hline G4 & $4.47 \pm 0.29$ & $1.21 \pm 0.23$ & $4.25 \pm 0.17$ & $1.05 \pm 0.14$ \\
\hline
\end{tabular}

$* \mathrm{P}<0.05$

$* * \mathrm{P}<0.01$

Table (7) : Mean values of pefloxacin residues $(\mu \mathrm{g} / \mathrm{g})$ in fresh hens tissues and organs.

\begin{tabular}{||c|c|c|c|c|c|c||}
\hline \multirow{2}{*}{$\begin{array}{c}\text { Drug } \\
\text { Tissues }\end{array}$} & \multicolumn{7}{|c|}{ Days post slaughter } \\
\cline { 2 - 7 } & $1 \mathrm{st}$ & 3 rd & 5 th & 7 th & 10th & 15 th \\
\hline Muscles & $1.31 \pm 0.20$ & $0.83 \pm 0.10$ & $0.44 \pm 0.05$ & 00 & 00 & 00 \\
\hline Liver & $2.63 \pm 0.25$ & $1.73 \pm 0.14$ & $0.39 \pm 0.04$ & 00 & 00 & 00 \\
\hline Kidney & $1.22 \pm 0.36$ & $1.03 \pm 0.21$ & $0.21 \pm 0.09$ & 00 & 00 & 00 \\
\hline Gizzard & $1.71 \pm 0.51$ & $1.16 \pm 0.17$ & $0.52 \pm 0.12$ & 00 & 00 & 00 \\
\hline Skin & $2.24 \pm 0.25$ & $1.38 \pm 0.14$ & $1.02 \pm 0.15$ & $0.76 \pm 0.15$ & 0.05 & 00 \\
\hline Fat & $2.68 \pm 0.92$ & $1.89 \pm 0.51$ & $1.27 \pm 0.21$ & $0.97 \pm 0.21$ & 0.06 & 00 \\
\hline \hline
\end{tabular}




\section{REFERENCES}

Abdallah, Amany (1993) : Clinico pathological studies on the effect of some antibiotic used in chickens.Ph.D.Thesis (Cinical Pathology) Fac.Vet.Med, Zag. Univ.

Abd Elhamid, H.; Ellakany, H. and Hussien, A. (2006) : Incidence of Salmonella infection in chickens in Libya 4th Scientific Conference Suez Canal University.

Abu Zaid, Omima (1987) : Liver function tests in relation to some bacterial and viral diseases in chickens. M.V.Sc. Thesis (Biochemistry) Faculty of Vet. Med.Zag. Uni.

Adel, H. H. (2004) : Clinicopathological studies on salmonellosis in chicken. M V Sc Thesis of clinical pathology Suez Canal University

Alexander, F. (1985) : An introduction to Veterinary Pharmacology, $4^{\text {th }}$ Ed. Longman (london and New York ).

Avril, J.; Couete, I. and Plessis P. (1995) : Susceptibility to quinolones of Salmonella isolated from men and animals.Pathol. Biol.43, 4:270-300.

Badr, Y. (2003) : Evaluation of both drugs and preventive methods used for protect-ion from Salmonella and E.Coli infections in chicks.PH.D.Thesis,Fac.of Vet.,Med,Zag. Uni.

Bartels, H. (1971) : Determination of serum Creatinine Clin. Chem. Acte 32-81.

Bryan, C.; John, J. and Robrecht, F. (1998) : Comparison of the efficacies of three fluoroqu- inolone, one of antimicrobial agents, given as continous or pulsed- water medication, against $\mathrm{E}$. coli infection in chickens. Antim. Ag. and Chem.; 42 (1): 8387.

Coles, E. (1986) : Vet. Clinical Pathology. $4^{\text {th }}$ Ed.W.B. Saunders Comp., Philadelphia, London, Toronto, Mexico city, Rio de Janeiro, Sydney, Tokyo, Hong Kong.

Corry, J.; Sharma, M. and Bates, M. (1983) : Detection of antibiotic residues in milk and animal tissues. Technical series, Society for Applied Bacteriology. No. 18, 349370.

Dawaud, A. (1992) : Clinicopathological studies on fowl typhoid in chickens in Domiate Governorate. M.V.Sc. Thesis Fac. of Vet. Med., Zag Uni.

Doxey, D. (1971) : Veterinary Clinical pathology 15th Ed London.55 6-560.

Doumas, B. (1971) : Calorimetric method for determination of albumin. Clin Chem Acta (22).

Doumas, B.; Cartor, R.; Peers, T. and Schaffier, R. (1981) : A candidate reference method for determination of total protein in serum Clin.Chem.27,1642.

Dvorak, M.; Janeckova, I. and Strakova, J. (1987) : Tylosin concentrations in the blood and lungs of poultry after admmistradon in drinking water. Biologizace a chcmizace zivocishe vyroby veterinaria 23 (4) : 343. 
El-Sayed, Nagah, E.; Gad Gehan, N. and Wael,G. (2004) : Efficacy and side effects of pefl- oxacin in laying hens. Alex. J. Vet. Sci (21)1, 110-119.

Eslam, E. (2000) : Some pharmacological studies on florfeicol and its interaction with streptomycin in chickens. M.V.Sc.Thesis Fac. of Vet. Med., Zag University.

García, O.; Luders, C. and Puelles, I. (1999) : Comparative pharmacokinetics of enrofloxacin and ciprofloxacin in chickens. $J$ vet Pharmacol Therap; 22: 209-212.

Greenfield, J.; Bigland, C.; Mc causland, H. and Wood, C. (1972) : Control of Salmonella disease in turkey by poult injection. Poult Sci. 51: 523-526.

Jain, N. (1986) : Schalm's Vet. Haematology, $4^{\text {th }}$ Ed., Lea and Fibiger, Philadelphia, USA

John, D. (1982) : Clinical laboratory mothed for determination of alkaline phosphatease $9^{\text {th }}$ Ed. 580-581.

Kletter, Y.; Riklis, I. and Fabian, I. (1992) : Enhanced repopulation of murine hematopoietic organs in sublethally irradiated mice after treatment with ciprofloxacin. Blood; 78(7):85-91.

Kobayashi, H. (1985) : Summary of clinical studies on ciprofloxacin efficacy and adverse reactions. Proc. of the $14^{\text {th }}$ International Congress of Chemo. Kyoto, Japan.

Kaneko. J. (1989) : Clinical biochemistry of domestic animal Academic Press Inc New York,

Harrison, G. and Harrison, L. (1986) : Clinical Avian Medicine and Surgery.W.B. Saunders company Philadelphia, London, Toronto

Moustafa, A.; Masoud, E. and El-Ashram, A. (2008) : Studies On Streptococcal Infections Among Cultured Freshwater Fishes And Ducklings In Integrated Aquaculture System Zag. Vet. J. 36( 4)22-29.

Niyogi, D. and Bhowmik, M. (2003) : Toxic pathological changes of ciprofloxacin in broiler chickens. India Journal of Animal Science; 73(1): 12-15.

Omyma, K. I. ibrallem and Allum, R. ElAbdel Ateif, D. (1997) : Studies on some bacterial agents isolated from dead in shell chickens embryos and baby chicks in Sharkia Provicne. J. Egypt Vet. Med. Association, 57. No. 1: 747-763.

Pant, S.; Rao, G.; Sastry, G. Tripathi, H.; Jagmohan and Malik, A. (2005) : Pharmacokinetics and tissue residues of pefloxacin and its metabolite norfloxacin in broiler chickens British Poultry Science 46 (5) 615 620.

Petrie, A. and Watson, P. (1999) : Statistics for Veterinary and Animal Science 1stEd. 90-99, The Blackwell Science LTd, United Kingdom.

Reitman, S. and Frankel, S. (1957) : Calorimeric determination of transaminaes- 
es activity Am. J. Clin. Path .28:56.

Reynolds, J. (1995) : Martindal the Extra Pharmacapia.30thEd.The pharma. pres. London.

Roshdy, M. (2007) : Some pharmacological studies on pefloxacin in chickens.M. V. Sc. Thesis (Pharmacology) presented to Zagazig Univ.

Ross, J.; Halliday, W. and Jones, R. (1976) : Determination of serum transaminase activity. Amer.J. Clin. Path., 28: 58-68.

Roudaut, B. and Moretain, J. (1990) : Residues of macrolid antibiotics in eggs following medication of laying hens. Br. Poult. Sci. 31 (3): 661.

Seo, K.; Holt, P.; Gast, R. and Hofacre, C. (2000) : Elimination of Early Salmonella enteritid-is Infection After Treatment with
Competitive-Exclusion Culture and Enrofloxacin in Experimentally Infected Chicks. Poultry Science 79: 1408-1413.

Sun, Y.; Heo, E. and Kim, T. (2001) : Pefloxacin and ciprofloxacin increase UVAinduced edema and immune suppression. Photodermatol photoimmunol pholomed. 17 (4): 172-7.

Trinder, P. (1969) : Enzymatic calorimetric method for estimation of uric acid. Ann. Clin. Bioc.6:24

Turnbull, P. and Snoeyenbos, G. (1974) : Experimental Salmonellosis in the chicken. 1. Fate and host response in alimentary canal, liver, and spleen. Avian. Dis.18:15-17.

Wille, A.; Altay, G. and Erdem, B. (1988) : The Susceptibility of Salmonellaspp.to Various antibiotics. Mikrobiyol Bul. 22, 1:17-24. 
الملخص العربى
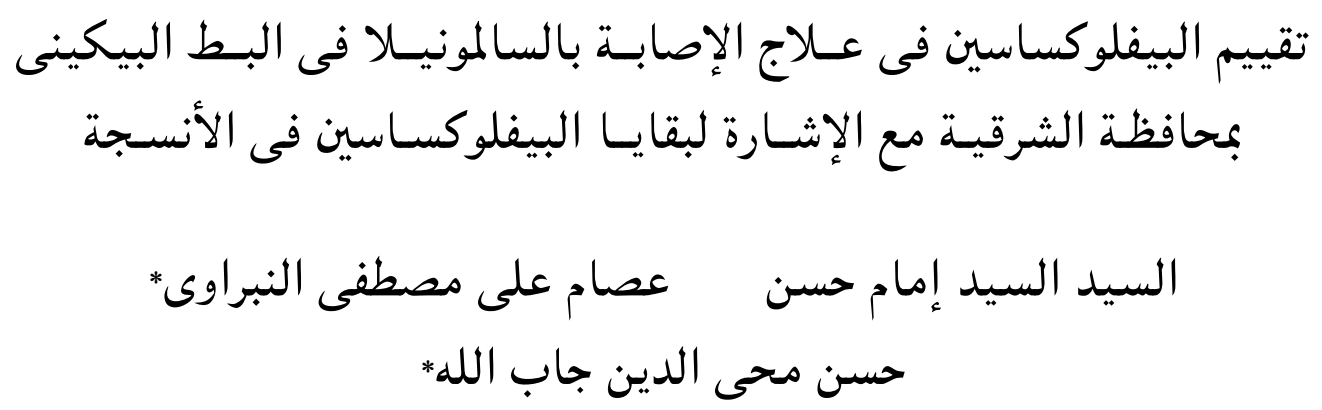

أقسام (الكيمياء وصحة الأغذية* ) معهد بحوث صحة الحيوان (فرع بالزقازيق)

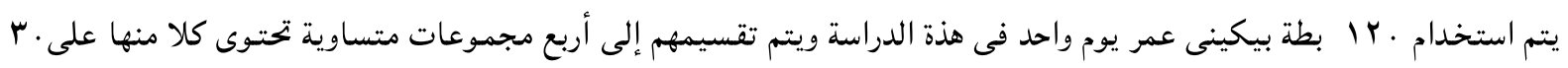

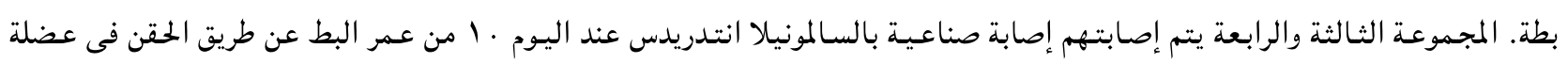

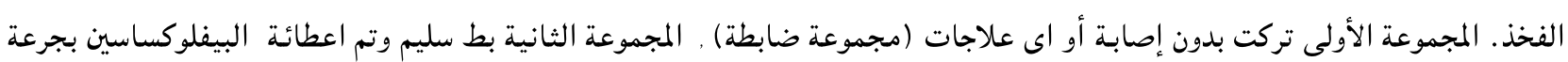

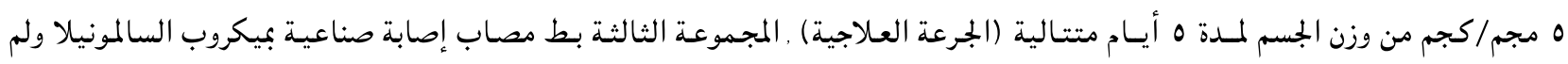

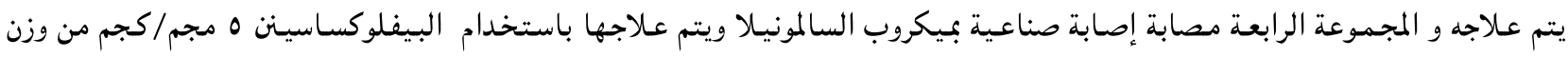

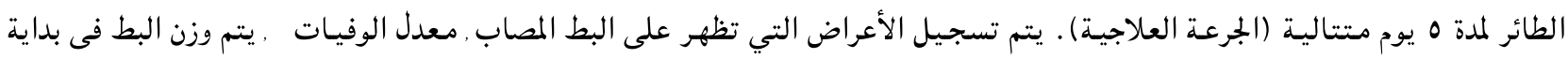

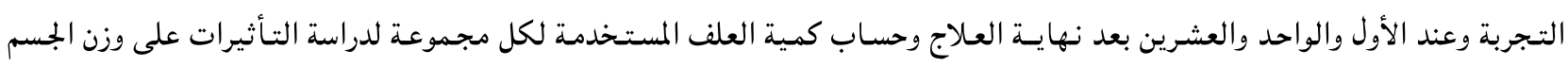

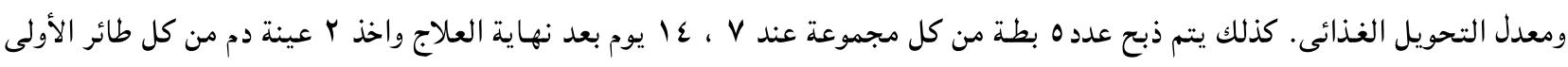

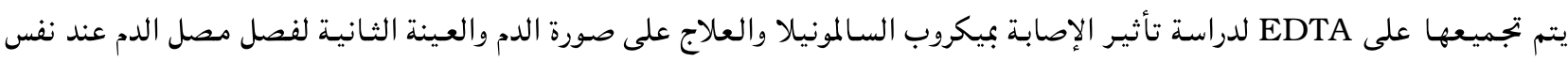

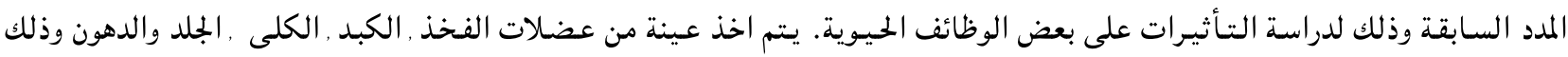

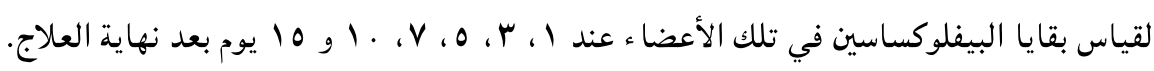
أوضحت الدراسة أن البيفلوكساسين بالجرعة العلاجية لة تأثيرات ضارة على صورة الدم ووظائف الكبد والكلى بالبط البيكينى السليم

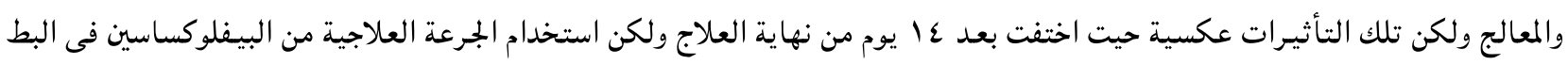
السليم أدى إلى زيادة فى وزن الجسم المكتسب وقلل معدل التحويل الغذائى.

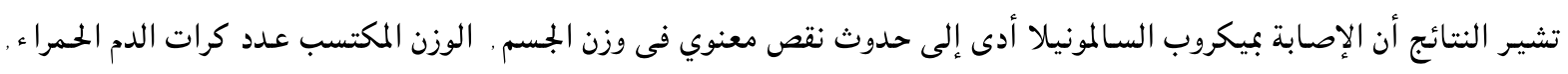

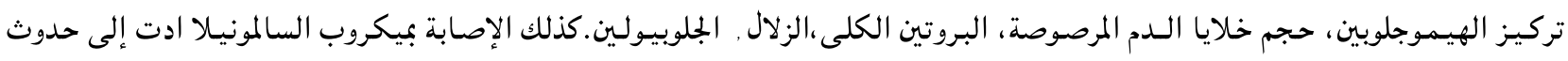

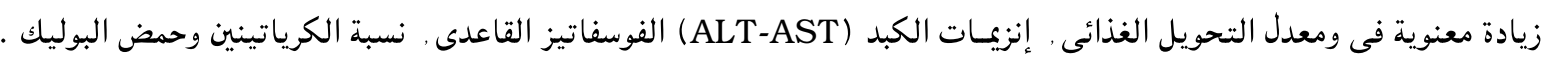

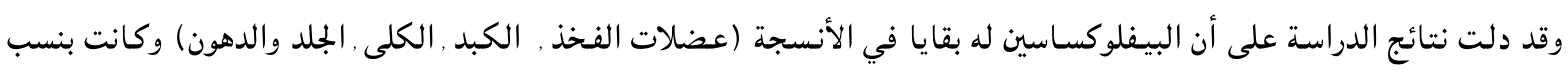

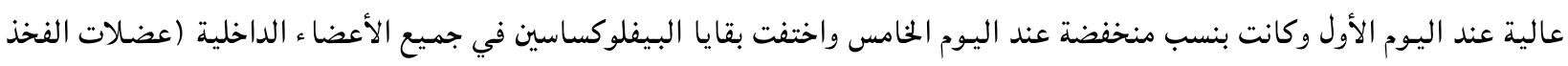


Emam, E. E.; et al...

الكبد , الكلى) عند اليوم السابع بعد نهاية العلاج بينما اختفت بقايا البيفلوكساسين فى الجلد والدهون عند اليوم الخامس عشر بعد نهاية

العلاج.

من كل ما سبق نلاحظ أن أستخدام البيفلوكساسين بالجرعة العلاجية لة تأثير فعال فى علاج الإصابة بالسالمونيلا وأدى إلى اختفاء

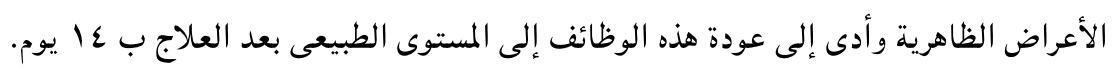

